Research article

\title{
INFLUENCE OF MARINATION ON SALMONELLA SPP. GROWTH IN BROILER BREAST FILLETS
}

\author{
BALTIĆ Tatjana ${ }^{1 *}$, BALTIĆ Ž. Milan², MIŠIĆ Dušan ${ }^{2}$ IVANOVIĆ Jelena ${ }^{2}$, JANJIĆ \\ Jelena $^{2}$, BOŠKOVIĆ Marija ${ }^{2}$, DOKMANOVIĆ Marija ${ }^{2}$ \\ ${ }^{1}$ Institute of Meat Hygiene and Technology, Belgrade, Serbia; ${ }^{2}$ Faculty of Veterinary Medicine, \\ University of Belgrade, Serbia
}

(Received 26 $6^{\text {th }}$ June 2014; Accepted 26 ${ }^{\text {th }}$ May 2015)

The aim of this study was to investigate the influence of marination, on the growth of Salmonella spp. in contaminated broiler breast fillets during storage. In the conducted study, broiler breast fillets were inoculated with a cocktail of different Salmonella strains and afterwards marinated in different solutions of table salt, sodium tripolyphosphate and/or sodium citrate. The total count of Salmonella spp. was examined on the $0,3^{\text {td }}, 6^{\text {th }}$ and $9^{\text {th }}$ day of storage. Broiler breast fillets salted in $6 \%$ solution of table salt were used as the control. Proximate composition and salt content, $\mathrm{pH}$ value and $\mathrm{a}_{\mathrm{w}}$ value, were determined as the meat quality parameters and parameters which can affect environmental conditions for bacterial growth, as well. Compared to initial contamination, Salmonella spp. count in marinated and salted fillets did not change significantly $(\mathrm{p}<0.001)$ until the $3^{\text {td }}$ and $6^{\text {th }}$ day of storage, respectively, but it increased significantly on the $9^{\text {th }}$ day of storage. Marination of broiler breast fillets in different solutions of table salt, sodium tripolyphosphate and/or sodium citrate had a significant influence $(\mathrm{p}<0.05 ; \mathrm{p}<0.01)$ on $\mathrm{pH}$ and $\mathrm{a}_{\mathrm{w}}$ value, moisture, ash and salt content in marinated broiler meat, but there was no significant influence $(\mathrm{p}>0.05)$ on protein and fat content in broiler meat. According to the results obtained it can be concluded that marination of broiler breast fillets in solutions containing table salt, sodium trpolyphosphate and/or citrate, in some way, can prolongate the lag phase of Salmonella spp. growth, where sodium citrate is more effective than sodium tripolyphosphate.

Key words: broiler meat, marinade, Salmonella spp., quality

\section{INTRODUCTION}

Contemporary lifestyle has led to increased demand for meat products, which beside the heat treatment does not require additional preparation in household conditions. Commercial, industrial marination of meat provides many benefits for both, producers and consumers. It can significantly decrease the meal preparing time, provide favorable sensory characteristics of the meat and furthermore, reduce the possibility of additional meat contamination in the household. On the other hand,

\footnotetext{
*Corresponding author: e-mail: tanja@inmesbgd.com
} 
responsibility of the manufacturers in terms of quality and safety of these products increases. Commercial marination of meat involves the addition of a water solution of table salt, phosphates and sometimes flavorings and other ingredients, by means of soaking, blending, tumbling or injecting [1]. Traditionally, meat has been marinated to improve flavor, tenderness and increase product shelf life [2]. Nowdays, it is known that marination affects the chemical, physical and microbiological quality of meat. What will be the effects of marination depends on the type of marinade, marination technique and quality of meat as a raw material as well. Industrial marination aims, above all, to improve the technological and sensory characteristics of meat. For this purpose, the most commonly used are alkaline marinades which consist of water, table salt and phosphates. Due to an increase in the $\mathrm{pH}$ value of meat, these marinades allow greater water uptake by the muscle, which eventually increases yield and juiciness of the meat. Moreover, marinades containing phosphates tend to reduce rancidity development and warmed-over flavor, increase shelf life, and improve the color of poultry meat [3]. Typical marinade solution for commercial broiler products is made of $90 \%$ water, $6 \%$ table salt (sodium chloride), and 4\% sodium tripolyphosphate [1]. In the meat industry, citric acid and sodium citrate are widely used in the $\mathrm{pH}$ control, metal chelating, and preservation [4]. Sodium citrate has a positive effect on color stability [5] and juiciness of meat [6]. As a replacement for phosphates in "phosphate-free" meat products, sodium citrate increases the water holding capacity, which results in increased juiciness [2]. Several studies have confirmed that phosphates exhibit a bacteriostatic effect against Gram-positive bacteria (Leuconostoc carnosum, Listeria monocytogenes, Staphylococcus aureus, Bacillus cereus, Bacillus stearothermophilus, Bacillus brevis, Bacillus subtilis, Bacillus sphaericus, Bacillus spp., Micrococcus luteus, Corynebacterium glutamicum), but that bacteriostatic effect on Gram-negative bacteria (Salmonella Typhimurium, Salmonella Enteritidis, Escherichia coli) is not significant [7-14]. Organic acid salts like sodium acetate, lactate and citrate have antibacterial effects on different food pathogens, including Staphylococcus aureus and Yersinia enterocolitica [15], Listeria monocytogenes, Escherichia coli [15,16] and Clostridium botulinum [17]. In the recent years, more attention has been paid to investigations of different phosphates and other marinade ingredients on the microbiological status and meat quality.

Marination is especially used for poultry products [18]. Poultry meat, compared to other types of meat, in terms of nutritional value, has many advantages. However, raw poultry meat is a potential source of pathogenic bacteria. The most commonly isolated are Salmonella spp., Campylobacter spp., Clostridium perfringens, Escherichia coli O157 and Listeria monocytogenes [19]. Poultry meat is one of the most commonly identified sources of Salmonella outbreaks in humans worldwide. Cause of poisoning commonly referred to Salmonella Enteritidis, S. Typhimurium and S. Heidelberg [20,21]. In 2010, 2,636 confirmed cases of salmonellosis in humans were recorded in Serbia, from which 2,536 were serotyped. Studies conducted by Rašeta et al. [22] clearly indicate that Salmonella isolated from poultry carcasses, pose a risk to the health of people in Serbia. Moreover, the only legislation defined safety criteria for semi- processed 
meat products, which is the marinated poultry meat, is the absence of Salmonella spp. (Commission Regulation No 2073/2005 on microbiological criteria for foodstuffs).

Therefore, the aim of this study was to investigate the influence of marination on the growth of Salmonella spp. in contaminated/inoculated broiler breast meat, but on chemical and physical quality parameters which can affect meat quality and environmental conditions for bacterial growth, as well.

\section{MATERIALS AND METHODS}

Deboned broiler breast meat ( $m$. pectoralis major), skinless, was produced in a local poultry slaughterhouse. On the day of slaughter, broiler breast meat placed on ice was submitted to the laboratory, where it was filleted into pieces weighing approximately $0.1 \mathrm{~kg}$ and divided into four groups. For marinade, table salt with 99 to $99.5 \%$ sodium chloride (Solana dd Tuzla, Bosnia and Herzegovina), a "Carfosel Genius" commercial mixture of sodium tripolyphosphate (Prayon, Belgium) and tri-sodium citrate dihydrate $\left(\mathrm{C}_{6} \mathrm{H}_{5} \mathrm{Na}_{3} \mathrm{O}_{7} \times 2 \mathrm{H}_{2} \mathrm{O}\right)$ (Merck, Germany) were used. Three different marinades and a solution of table salt $(6 \% \mathrm{NaCl})$ as a control (I group) were prepared for the experiment. The first marinade consisted of water, $6 \% \mathrm{NaCl}$ and $2 \%$ phosphate (II group), the second consisted of water, $6 \% \mathrm{NaCl}$ and $2 \%$ citrate (III group) and the third one consisted of water, $6 \% \mathrm{NaCl}, 1 \%$ phosphate and $1 \%$ citrate (IV group). For the preparation of the marinade, drinking water was used. Marinades have been prepared 24 hours before use, and afterwards refrigerated at $4 \pm 1{ }^{\circ} \mathrm{C}$.

For the experimental inoculation of the fillets, isolates of Salmonella Enteritidis (A1, A2, A3 and ATCC 13076) and Salmonella Typhimurium (ATCC 14028) were used. Salmonella Enteritidis A1 (Faculty of Veterinary Medicine, Belgrade, Serbia) was isolated from chicken liver, S. Enteritidis A2 (Institute of Meat Hygiene and Technology, Belgrade, Serbia) was isolated from mechanically deboned chicken meat, and $S$. Enteritidis A3 (Public Health Institute of Serbia "Dr Milan Jovanović Batut", Belgrade, Serbia) was isolated from feces of a child affected by salmonellosis. A cocktail of these strains was prepared from overnight (18h) cultures (Brain Heart Infusion, Merck, Germany), and a final concentration of $5.42 \log \mathrm{CFU} / \mathrm{mL}$ was obtained. Chicken breast fillets divided into four groups were inoculated with the Salmonella cocktail in the ratio of 1:10 $(1 \mathrm{~mL}$ cocktail/10 g of meat). After inoculation, the meat was left for $30 \mathrm{~min}$ in order for bacterial cells to attach to the meat surface.

Contaminated broiler breast fillets were soaked in the marinades and solution of table salt, as a control, in the ratio of 1:2 (100g of meat/ $200 \mathrm{~mL}$ of marinade or table salt solution). Marination process lasted $4 \mathrm{~h}$ at $4 \pm 1{ }^{\circ} \mathrm{C}$, with stirring at times. After 4 hours, the fillets were packed in sterile Stomacher bags and stored for 9 days under aerobic conditions at $4 \pm 1^{\circ} \mathrm{C}$.

Before experimental contamination, the presence of Salmonella spp. in broiler breast meat was analyzed according to the EN ISO 6579: 2002/A1:2007 method. In 
contaminated meat, count of Salmonella spp. was performed on the $0,3^{\text {rd }}, 6^{\text {th }}$ and $9^{\text {th }}$ day of storage, according to the method recommended by Pathania at al. [23]. On the testing day, from each group of fillets (I, II, III, IV), $20 \mathrm{~g}$ of meat was sampled, in triplicate. To each sample, $180 \mathrm{~mL}$ of Buffered Peptone Water (BPW), (Merck, Germany) was added and homogenized $30 \mathrm{sec}$ in a Stomacher. The count of Salmonella spp. in contaminated fillets was determined by applying $0.1 \mathrm{~mL}$ of appropriate sample dilution on the surface of Xylose Lysine Tergitol-4 agar (XLT4), (Merck, Germany). Inoculated plates were incubated for $24 \mathrm{~h}$ at $37^{\circ} \mathrm{C}$. After incubation, the characteristic black colonies of Salmonella spp. were counted. The results of microbiological examinations are expressed as $\log \mathrm{CFU} / \mathrm{g}$ of meat.

Chemical analyzes were performed on the day of the experiment setup ( 0 day). The proximate composition of the chicken fillets was determined using standard ISO methods. Protein content $(\mathrm{N} \times 6.25)$ was quantified by the Kjeldahl procedure on Kjeltec 8400 Analyzer Unit (Foss, Sweden), according to ISO 937:1978 method. Moisture content was determined by drying at $103 \pm 2{ }^{\circ} \mathrm{C}$ to constant mass (ISO 1442:1998). Free fat content was determined by extraction with petroleum ether in a Soxhlet apparatus (ISO 1444:1996). Ash content was determined by combustion of the sample at $550^{\circ} \mathrm{C}$ to constant weight (ISO 936:1998), while salt content was determined by silver nitrate titration, according to ISO 1841-1: 1996 method.

The water activity $\left(\mathrm{a}_{\mathrm{w}}\right)$ values of chicken fillets were determined on the 0 and $9^{\text {th }}$ day of storage. The $a_{w}$ value was calculated from water-phase salt (WPS) with the equation used by Giménez and Dalgaard [24]:

$$
\mathrm{a}_{\mathrm{w}}=1-0,0052471 \times \mathrm{WPS}-0,00012206 \times \mathrm{WPS}^{2}
$$

Water-phase salt (WPS) was calculated from the total salt and moisture content of the meat, by using the equation:

$$
\text { WPS }(\%)=\% \text { salt } / \% \text { salt }+\% \text { moisture } \times 100
$$

The $\mathrm{pH}$ values of chicken fillets were determined on the $0,3^{\text {rd }}, 6^{\text {th }}$ and $9^{\text {th }}$ day. Determination of the $\mathrm{pH}$ value in marinated fillets was performed directly, with "Testo 150 ” pH- meter (Testo, Germany), according to ISO 2917:1999 method.

Statistical analysis of the results was elaborated using software GrapfPad Prism version 5.00 for Windows, GraphPad Software, San Diego, California USA, www.graphpad. com.

\section{RESULTS}

The counts of Salmonella spp. in broiler breast fillets during 9 days of storage are presented in Table 1. Before experimental contamination, broiler breast fillets were free of Salmonella spp. On the 0 day of storage, there were no significant differences 
( $\mathrm{p}>0.05)$ between Salmonella spp. counts in marinated (II, III, IV group) and salted breast fillets (I group), but on the $3^{\text {rd }}$ and $6^{\text {th }}$ day of storage significant differences $(p<0.01 ; p<0.05)$ between groups were found. Until the $6^{\text {th }}$ day of storage, Salmonella spp. count was the lowest in control group I and the highest in group IV. From $\sigma^{\text {th }}$ to $9^{\text {th }}$ day of storage, Salmonella spp. count in all tested groups reached count of more than $5 \log \mathrm{CFU} / \mathrm{g}$. Contrary to previous results, on the $9^{\text {th }}$ day of storage the lowest count was in group II and highest in group III, where the Salmonella spp. count was significantly higher $(\mathrm{p}<0.05)$ from the Salmonella spp. count in group IV.

Table 1. The changes of Salmonella spp. count $(\log \mathrm{CFU} / \mathrm{g})$ in broiler breast fillets during storage

\begin{tabular}{ccccc}
\hline \multirow{2}{*}{ Group } & \multicolumn{4}{c}{ Storage days } \\
\cline { 2 - 5 } & $\mathbf{0}$ & $3^{\text {rd }}$ & $\mathbf{6}^{\text {th }}$ & $\mathbf{9}^{\text {th }}$ \\
\cline { 2 - 5 } & \multicolumn{4}{c}{$\overline{\mathbf{X}} \pm \mathbf{S d}$} \\
\hline I & $3.37 \pm 0.55$ & $2.92 \pm 0.30^{\mathrm{aA}}$ & $3.07 \pm 0.45^{\mathrm{AB}}$ & $5.91 \pm 0.32$ \\
II & $3.65 \pm 0.39$ & $3.29 \pm 0.34^{\mathrm{B}}$ & $4.32 \pm 0.34^{\mathrm{AC}}$ & $5.62 \pm 0.48$ \\
III & $3.64 \pm 0.35$ & $3.57 \pm 0.54^{\mathrm{a}}$ & $3.34 \pm 0.27^{\mathrm{CD}}$ & $6.18 \pm 0.55^{\mathrm{a}}$ \\
IV & $3.50 \pm 0.36$ & $3.64 \pm 0.17^{\mathrm{AB}}$ & $4.40 \pm 0.48^{\mathrm{BD}}$ & $5.44 \pm 0.29^{\mathrm{a}}$ \\
\hline
\end{tabular}

Legend: same letters A-D $\mathrm{p}<0.01$; a $\mathrm{p}<0.05 ; \overline{\mathrm{X}}-$ Mean value; Sd - Standard deviation

Comparing the storage days, a statistically significant difference in the Salmonella spp. count within each group was tested (Table 2). Within group I, significant difference in Salmonella spp. count was not established until the $6^{\text {th }}$ day of storage. However, difference in Salmonella spp. count between $9^{\text {th }}$ day and the other two comparing days was significant $(\mathrm{p}<0.001)$. In marinated breast fillets (II, III and IV group), there was no significant difference $(\mathrm{p}>0.05)$ in Salmonella spp. count between the 0 and $3^{\text {rd }}$ day of storage $(\mathrm{p}>0.05)$. On the other comparing days, Salmonella spp.count in marinated fillets (II, III and IV group) were changed significantly, at different significance levels of $\mathrm{p}<0.001$ or $\mathrm{p}<0.01$.

Table 2. The statistical significance of differences in Salmonella spp. count within groups, comparing storage days

\begin{tabular}{cccccc}
\hline \multirow{2}{*}{$\begin{array}{c}\text { Comparing } \\
\text { days }\end{array}$} & \multicolumn{5}{c}{ Group } \\
\cline { 2 - 5 } & I & II & III & IV \\
\hline $0-3$ & $\mathrm{~ns}$ & $\mathrm{p}$ & $\mathrm{ns}$ & $\mathrm{ns}$ \\
\hline $0-6$ & $\mathrm{~ns}$ & $* *$ & $* * *$ & $* *$ \\
$0-9$ & $* * *$ & $* * *$ & $* * *$ & $* * *$ \\
$3-6$ & $\mathrm{~ns}$ & $* * *$ & $\mathrm{~ns}$ & $* * *$ \\
$3-9$ & $* * *$ & $* * *$ & $* * *$ & $* * *$ \\
$6-9$ & $* * *$ & $* * *$ & $* * *$ & $* *$ \\
\hline
\end{tabular}

Legend: ${ }^{* * *} \mathrm{p}<0.001 ;{ }^{* *} \mathrm{p}<0.01$; ns - not significant 
Data for proximate composition (proteins, fat, moisture and ash content) and salt content in salted and marinated breast fillets are presented in Table 3 . The obtained results indicated that marination has no significant influence $(\mathrm{p}>0.05)$ on protein and fat content in marinated fillets, but has significant influence on moisture, ash and salt content. Moisture content in marinated breast fillets was significantly $(p<0.01$; $\mathrm{p}<0.05)$ lower compared to moisture content in salted breast fillets. Ash content was significantly $(\mathrm{p}<0.01)$ higher in samples of group III and group IV, compared to ash content in control group I and samples of group II, as well. Furthermore, salt content in samples of group III and IV was significantly $(\mathrm{p}<0.01 ; \mathrm{p}<0.05)$ higher than salt content in samples of group I and group II.

Table 3. The proximate composition and salt content in broiler breast fillets on the 0 day of storage

\begin{tabular}{cccccc}
\hline \multirow{2}{*}{ Group } & Proteins (\%) & Fat (\%) & Moisture (\%) & Ash (\%) & Salt (\%) \\
\cline { 2 - 6 } & \multicolumn{5}{c}{$\overline{\mathbf{X}} \pm \mathbf{S d}$} \\
\hline I & $16.33 \pm 0.51$ & $1.92 \pm 0.20$ & $78.10 \pm 0.13^{\mathrm{Aab}}$ & $3.65 \pm 0.07^{\mathrm{Aa}}$ & $2.60 \pm 0.05^{\mathrm{Aa}}$ \\
II & $16.00 \pm 0.33$ & $1.92 \pm 0.20$ & $77.58 \pm 0.11^{\mathrm{b}}$ & $3.62 \pm 0.09^{\mathrm{BC}}$ & $2.54 \pm 0.09^{\mathrm{BC}}$ \\
III & $16.15 \pm 0.34$ & $1.92 \pm 0.20$ & $77.53 \pm 0.26^{\mathrm{a}}$ & $4.40 \pm 0.09^{\mathrm{ABD}}$ & $3.35 \pm 0.09^{\mathrm{ABD}}$ \\
IV & $16.62 \pm 1.05$ & $2.00 \pm 0.31$ & $77.54 \pm 0.94^{\mathrm{A}}$ & $3.84 \pm 0.12^{\mathrm{aCD}}$ & $2.79 \pm 0.18^{\mathrm{aCD}}$ \\
\hline
\end{tabular}

Legend: same letters A-D p <0.01; a-b $\mathrm{p}<0.05 ; \overline{\mathrm{X}}-$ Mean value; $\mathrm{Sd}-$ Standard deviation

Table 4 shows the $\mathrm{pH}$ values of broiler breast fillets during 9 days of storage. As it was expected, $\mathrm{pH}$ values of marinated samples were significantly higher $(\mathrm{p}<0.01)$ compared to $\mathrm{pH}$ values of control samples. Similar data were obtained on the $3^{\text {rd }}, 6^{\text {th }}$ and $9^{\text {th }}$ day of storage, when statistically significant differences $(\mathrm{p}<0.01)$ between $\mathrm{pH}$ values of marinated and salted breast fillets were established. From the beginning to the end of the study, the $\mathrm{pH}$ values were gradually increasing in all four groups of samples.

Table 4. $\mathrm{pH}$ values of broiler breast fillets during storage

\begin{tabular}{ccccc}
\hline \multirow{2}{*}{ Group } & \multicolumn{4}{c}{ Day of storage } \\
\cline { 2 - 5 } & $\mathbf{0}$ & $3^{\text {rd }}$ & $6^{\text {th }}$ & $\mathbf{9}^{\text {th }}$ \\
\cline { 2 - 5 } & \multicolumn{4}{c}{$\overline{\mathbf{X}} \pm \mathbf{S d}$} \\
\hline I & $5.94 \pm 0.02^{\mathrm{ABC}}$ & $6.15 \pm 0.02^{\mathrm{AB}}$ & $6.06 \pm 0.02^{\mathrm{ABC}}$ & $6.38 \pm 0.01^{\mathrm{AB}}$ \\
II & $6.09 \pm 0.01^{\mathrm{ADE}}$ & $6.20 \pm 0.02^{\mathrm{C}}$ & $6.21 \pm 0.03^{\mathrm{AD}}$ & $6.45 \pm 0.03^{\mathrm{CD}}$ \\
III & $6.04 \pm 0.01^{\mathrm{BDF}}$ & $5.98 \pm 0.07^{\mathrm{ACD}}$ & $6.13 \pm 0.05^{\mathrm{BDE}}$ & $6.28 \pm 0.05^{\mathrm{ACE}}$ \\
IV & $6.25 \pm 0.03^{\mathrm{CEF}}$ & $6.25 \pm 0.01^{\mathrm{BD}}$ & $6.20 \pm 0.02^{\mathrm{CE}}$ & $6.58 \pm 0.08^{\mathrm{BDE}}$ \\
\hline
\end{tabular}

Legend: A-F statistical significance of $\mathrm{p} \leq 0.01 ; \overline{\mathrm{X}}-$ Mean value; $\mathrm{Sd}$ - Standard deviation

Data for water activity $\left(\mathrm{a}_{\mathrm{w}}\right)$ in salted and marinated breast fillets are shown in Table 5. On the 0 day, the lowest $a_{w}$ value was established in the samples of group III. This 
value was significantly lower $(\mathrm{p}<0.01)$ from $\mathrm{a}_{\mathrm{w}}$ values in group II and group IV and control group I, as well. The same significance of differences was observed on the $9^{\text {th }}$ day of storage.

Table 5. Water activity $\left(\mathrm{a}_{\mathrm{w}}\right)$ values in broiler breast fillets during storage

\begin{tabular}{ccc}
\hline \multirow{2}{*}{ Groups } & \multicolumn{2}{c}{ Day of storage } \\
\cline { 2 - 3 } & \multicolumn{2}{c}{$\mathbf{0} \overline{\mathbf{X}} \pm \mathbf{S d}$} \\
\cline { 2 - 3 } & $0.982^{\mathrm{AB}} \pm 0.001$ & $0.984^{\mathrm{ABa}} \pm 0.001$ \\
$\mathrm{~S}$ & $0.982^{\mathrm{CD}} \pm 0.001$ & $0.982^{\mathrm{AC}} \pm 0.001$ \\
$\mathrm{SF}$ & $0.976^{\mathrm{ACE}} \pm 0.001$ & $0.979^{\mathrm{BCD}} \pm 0.001$ \\
$\mathrm{SC}$ & $0.980^{\mathrm{BDE}} \pm 0.001$ & $0.983^{\mathrm{aD}} \pm 0.001$ \\
$\mathrm{SFC}$ & &
\end{tabular}

Legend: ${ }^{A-E}$ statistical significance of $\mathrm{p} \leq 0.01$; statistical significance of $\mathrm{p} \leq 0.05 ; \overline{\mathrm{X}} \pm-$ Mean value; $\mathrm{Sd}$ - Standard deviation

Changes of $\mathrm{a}_{\mathrm{w}}$ values during storage, within the control group I and experimental groups (II, III and IV) are shown in Graph 1.

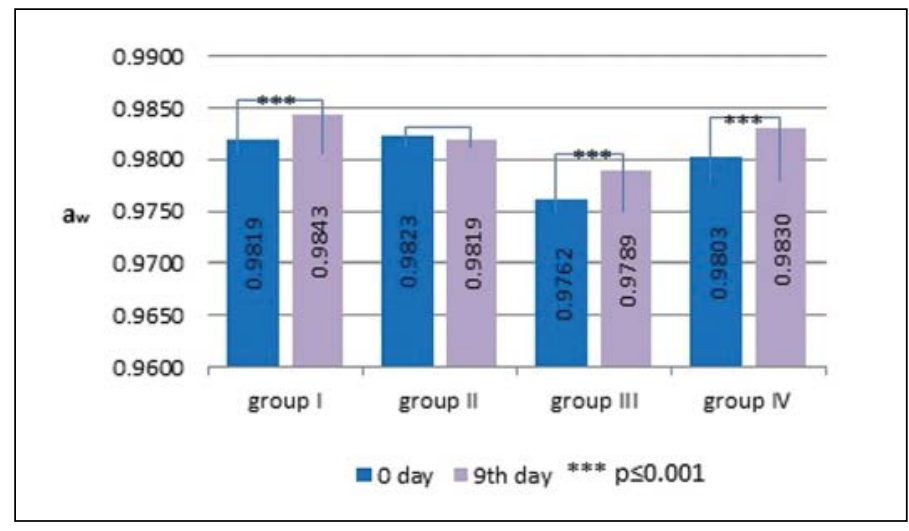

Graph 1. Statistical significance of differences in $\mathrm{a}_{\mathrm{w}}$ values change during storage

Comparing the $\mathrm{a}_{\mathrm{w}}$ values on the 0 and $9^{\text {th }}$ day of storage, significant differences $(p<0.001)$ were established within group III, group IV and the control group I, where $\mathrm{a}_{\mathrm{w}}$ values were increasing during storage.

\section{DISCUSSION}

Salmonella species are highly resistant microorganisms, able to survive longer periods in foods where its multiplication for some reason is not possible [25]. The optimum $\mathrm{pH}$ values for the growth of most Salmonella species ranged from 6.5-7.5, but they can grow in the range of 4.5-9.0. Salmonella species also survive in the food sample with is 
$\mathrm{a}_{\mathrm{w}} \geq 0.94$ [26]. Results for the proximate composition and salt content have shown that marination of broiler breast fillets in solutions of table salt, sodium tripolyphosphate and/or sodium citrate contributed to the change in moisture, ash and salt content in chicken fillets but had no influence on the protein and fat content compared to control ( $6 \%$ table salt solution). Marination of broiler breast fillets in a solution of $6 \%$ table salt and $2 \%$ sodium citrate has significant influence on the salt content in the meat, with a resulting significant decrease of $\mathrm{a}_{\mathrm{w}}$ values in group III samples. However, determined $\mathrm{a}_{\mathrm{w}}$ values in all tested groups were well above the limit value of 0.94 and were not a limiting factor for the growth of Salmonella spp. in marinated broiler meat.

Investigations on the $\mathrm{pH}$ values in salted and marinated fillets have shown that the $\mathrm{pH}$ values of marinated fillets were significantly higher than the $\mathrm{pH}$ value of salted fillets. Carroll et al. [27] examined the influence of marination on the $\mathrm{pH}$ value of turkey fillets. According to their data, there was no statistically significant difference between the $\mathrm{pH}$ value of fillets marinated in a solution of $1.5 \% \mathrm{NaCl}$ and $0.75 \%$ sodium citrate, and control samples marinated in a solution of $1.5 \% \mathrm{NaCl}$ and $0.45 \%$ tripolyphosphate. Ergezer and Gokce [28] achieved the most effective increase in $\mathrm{pH}$ value of turkey breast meat with a combination of $2 \% \mathrm{NaCl}$ and $2 \%$ sodium tripolyphosphate. Our study has shown that the $\mathrm{pH}$ values in group II samples were significantly higher compared to $\mathrm{pH}$ values in the fillets from group III. During 9 days of storage, the most significant increase in $\mathrm{pH}$ value was achieved by a combination of $6 \% \mathrm{NaCl}, 1 \%$ sodium tripolyphosphate and $1 \%$ citrate, and these values were significantly higher compared to $\mathrm{pH}$ values in the control and other two groups. These data are in accordance with the research of Killefer et al. [29], who found that the ultimate $\mathrm{pH}$ values of pork treated with saline solution, phosphate and citrate were higher compared to the control samples treated with phosphates only.

Perko- Mäkela et al. [30] have reported that a single factor such as the $\mathrm{pH}$ value can reduce survival of bacteria such as Campylobacter jejuni in marinades but that the effect of $\mathrm{pH}$ is limited on marinated chicken products, which is confirmed by our survey. We found that marination has no significant influence on the reduction of Salmonella population in marinated broiler breast fillets, but results indicates that the growth of Salmonella spp. in marinated broiler meat could be delayed. Shelef and Seiter [31] have reported the suppression of microbial growth by polyphosphates and suggested that the antimicrobial activity of these compounds can be attributed to their ability to chelate cations essential for microbial growth. However, the $\mathrm{pH}$ value increased gradually during storage which was probably the reason for an increase in the number of Salmonella in all groups tested. Long et al. [32] found that the bacteriostatic effect of phosphates is not significant, and that is displayed when using acidic phosphates or a combination of phosphates with other additives, such as nisin, EDTA, sodium chloride, nitrate, eritorbat and others, as confirmed by our survey. Lee et al. [15] after testing the antimicrobial activity of citrate and acetate in vitro, concluded that citrate has a weak antimicrobial activity against gram-negative bacteria, and that the combination of citrate and acetate does not increase this activity. Similar results were obtained in 
the study of Sallam et al. [33] who, after testing the antimicrobial and antioxidant activity of sodium acetate, lactate and citrate, concluded that sodium acetate is more effective compared to sodium lactate and sodium citrate.

In our trial, Salmonella spp. count in marinated and salted fillets did not differ significantly until the $3^{\text {rd }}$ and $6^{\text {th }}$ day of storage, respectively. However, to the end of study, Salmonella spp. counts increased significantly and values above $5 \log \mathrm{CFU} / \mathrm{g}$ were established in all tested groups. During 9 days of storage, the most significant increase in $\mathrm{pH}$ value was achieved by a combination of $6 \% \mathrm{NaCl}, 1 \%$ sodium tripolyphosphate and $1 \%$ citrate, and these values were higher compared to $\mathrm{pH}$ values in the control and other two groups. It seems that these relatively high $\mathrm{pH}$ values contributed to an increase of Salmonella spp. in samples of group IV.

From the results obtained, it can be concluded that sodium tripolyphosphate and sodium citrate have an influence on moisture and salt content in marinated breast fillets and consequently affect the change in $a_{w}$ value of meat. Solution of table salt and sodium citrate reduces the $\mathrm{a}_{\mathrm{w}}$ value in marinated fillets, but not at a level which could entirely inhibit the growth of Salmonella spp. The most effective increase was in $\mathrm{pH}$ value, and consequently an increased juiciness of the breast fillets was achieved by marination in a solution of table salt, sodium tripolyphosphate and sodium citrate. While improving quality, this combination of salts stimulates intensive Salmonella spp. growth, probably because of the lower citrate concentration in this marinade. The marinade which consisted of table salt and sodium tripolyphosphate did not show an inhibitory effect on Salmonella spp. growth. Lower Salmonella spp. count in salted fillets is probably a consequence of table salt ability to cause cellular plasmolysis. These results emphasize the importance of adhering to strict hygienic and quality control standards throughout the processing of marinated broiler meat.

\section{Acknowledgements}

This paper was supported by the Ministry of Education, Science and Technological Development of the Republic of Serbia, Project "Selected biological hazards to the safety/quality of food of animal origin and the control measures from farm to consumer" (Project No. TR 31034). The authors wish to express their gratitude to the Institute of Meat Hygiene and Technology Belgrade and to the Faculty of Veterinary Medicine Belgrade

\section{REFERENCES}

1. Smith DP and Acton JC: Marination, cooking and curing of poultry products. In: Poultry Meat Processing. Boca Raton, FL: CRC Press; 2001, 257-280.

2. Alvarado $C$ and McKee S: Marination to Improve Functional Properties and Safety of Poultry Meat. J Appl Poult Res 2007, 16: 113-120.

3. Lyon BG, Smith DP, Savage EM: Descriptive Sensory Analysis of Broiler Breast Fillets Marinated in Phosphate, Salt, and Acid Solutions. Poultry Sci 2005, 84: 345-349. 
4. Sammel LM, Claus JR, Greaser ML, Richards MP: Investigation of mechanisms by which sodium citrate reduces the pink color defect in cooked ground turkey. Meat Sci 2006, 72: $585-595$.

5. Holmer SF, Kutzler LW, McKeith FK, Killefer J: Sodium citrate as a replacement for sodium chloride in a brine solution when evaluated in cows of different backfat thickness. Meat Sci 2009, 81: 349-356.

6. Stephens JW, Dikeman ME, Unruh JA, Haub MD, Tokach MD: Effects of pre-rigor injection of sodium citrate or acetate, or post-rigor injection of phosphate plus salt on post-mortem glycolysis, $\mathrm{pH}$, and pork quality attributes. Meat Sci 2006, 74: 727-737.

7. Buňková L, Pleva P, Buňka F, Valášek P, Kráčmar S: Antibacterial effects of commercially available phosphates on selected microorganisms. Acta Univ Agric Et Silvic Mendel Brun 2008, 56: 19-24.

8. Dickson JS, Cutter CGN, Siragusa GR: Antimicrobial effects of trisodium phosphate against bacteria attached to beef tissue. J Food Prot 1994, 57: 952-955.

9. Feiner G: Meat products handbook - Practical science and technology. Cambridge, England: Woodhead Publishing Limited; 2006, 72 -83.

10. Lampila LE and Godber JP: Food Phosphates. In: Food Additives - $2^{\text {nd }}$ edition. New York, NY: Marcel Dekker; 2002, 869-963.

11. Molins RA: Phosphates in Food. CRC Press, Inc., Boca Raton, 1991: 121- 155.

12. Molins RA, Kraft AA, Olson DG: Effect of Phosphates on Bacterial Growth in Refrigerated Uncooked Bratwurst. J Food Sci 1985, 50: 531-532.

13. Sofos JN: Use of phosphates in low-sodium meat products. Food Technol 1986, 40: 53-63.

14. Tompkin RB: Indirect antimicrobial effects in foods: Phosphates. J Food Safety, 1984, 6: 13-27.

15. Lee YL, Cesario T, Owens J, Shanbrom E, Thrupp LD: Antibacterial activity of citrate and acetate. Nutrition 2002, 18: 665-666.

16. McWilliam Leitch EC and Stewart CS: Susceptibility of Escherichia coli O157 and non-O157 isolates to lactate. Lett in Appl Microbiol 2002, 35: 176-180.

17. Juneja VK and Thippareddi H: Inhibitory effects of organic acid salts on growth of Clostridium perfringens from spore inocula during chilling of marinated ground turkey breast. Int J Food Microbiol 2004, 93: 155 - 163.

18. Bjorkroth J. Microbiological ecology of marinated meat products. Meat Sci 2005, 70: 477 480.

19. Mead GC: Microbiological quality of poultry meat: a review. Brasilian Journal of Poultry Science 2004, 6(3): 135- 142.

20. Boyen F, Haesebrouck F, Maes D, Van Immerseel F, Ducatelle R,Pasmans F: Non-typhoidal Salmonella infections in pigs: A closer look at epidemiology, pathogenesis and control. Vet Microbiol 2008, 130(1-2): 1-19.

21. Velebit B, Mirilović M, Saičić S: Primenljivost metode multipleks lančane reakcije polimeraze u otkrivanju i identifikaciji vrsta salmonela. Tehnologija mesa 2007, 49, (3-4): 174-182.

22. Rašeta M, Teodorović V, Bunčić O, Katić V, Branković Lazić I, Polaček V, Vidanović D: Antibiotic resistance and molecular studies on Salmonella enterica subspecies enterica serovar Infantis isolated in human cases and broiler carcasses. Acta Veterinaria (Beograd) 2014, 64(2): 257-268.

23. Pathania A, McKee SR, Bilgili SF, Singh M: Antimicrobial activity of commercial marinades agains multiple strains of Salmonella spp.. Int J Food Microbiol 2010, 139: 214-217. 
24. Giménez B and Dalgaard P: Modelling and predicting the simultaneous growth of Listeria monocytogenes and spoilage micro-organisms in cold-smoked salmon. J Appl Microbiol 2004, 96: 96-109.

25. Karabasil N, Teodorović V, Dimitrijević M, Pavlićević N, Kureljušić J, Đurić S, Sočo I, Savić Radovanović R: Behavior of Salmonella Typhimurium in pork minced meat and pork skin at different storage temperatures. Acta Veterinaria (Beograd) 2013, 63(5-6):487-498.

26. Lawley R, Curtis L, Davis J: Salmonella. In: The Food Safety Hazard Guidebook. Cambridge, UK: RCS Publishing; 2008, 60- 66.

27. Carroll C D, Alvarado C Z, Brashears M M, Thompson L D, Boyce J: Marination of turkey breast fillets to control the growth of Listeria monocytogenes and improve meat quality in deli loaves. Poult Sci 2007, 86:150-155.

28. Ergezer H and Gokce R: Comparison of marinating with two different types of marinade on some quality and sensory characteristics of turkey breast meat. J Anim Vet Adv 2011,10(1): 60-67.

29. Killefer J: Effect of enhancement of pork and beef on post mortem events. In: Proceedings of the $59^{\text {th }}$ reciprocal meats conference, June 20-23, Lexington, Kentucky, 2004.

30. Perko-Mäkelä P, Koljonen M, Miettinen M, Hänninen ML: Survival of Campylobacter jejuni in marinated and nonmarinated chicken products. J Food Safety 2000, 20(4): 209-216.

31. Shelef AL and Seiter J: Indirect and miscellaneous antimicrobials. In: Antimicrobials in food, $3^{\text {rd }}$ ed. Boca Raton, FL: CRC Press; 2005, 573-596.

32. Long NHBS, Gál R., Buňka F: Use of phosphates in meat products. Afr J Biotechnol 2011, 10(86): 19874-19882.

33. Sallam KI: Antimicrobial and antioxidant effects of sodium acetate, sodium lactate, and sodium citrate in refrigerated sliced salmon. Food Control 2007, 18: 566-575.

\title{
UTICAJ MARINIRANJA NA RAST SALMONELLA SPP. U MESU GRUDI BROJLERA
}

\author{
BALTIĆ Tatjana, BALTIĆ Ž. Milan, MIŠIĆ Dušan IVANOVIĆ Jelena, JANJIĆ \\ Jelena, BOŠKOVIĆ Marija, DOKMANOVIĆ Marija
}

Cilj ovog rada bio je da se ispita uticaj mariniranja na rast Salmonella spp. u kontaminiranom mesu grudi brojlera tokom skladištenja. U sprovedenom istraživanju, fileti grudi brojlera su inokulisani mešanom kulturom različitih Salmonella serotipova, a zatim su marinirani u različitim rastvorima kuhinjske soli, natrijum tripolifosfata i/ ili natrijum citrata. Ukupan broj Salmonella spp. odredivan je nultog, 3., 6. i 9. dana skladištenja. Fileti grudi brojlera potapani u $6 \%$ rastvor kuhinjske soli korišćeni su kao kontrola. Osnovni hemijski sastav i sadržaj soli, $\mathrm{pH}$ i a $\mathrm{w}_{\mathrm{w}}$ vrednost mesa, određivani su kao parametri kvaliteta mesa, ali i kao parametari koji mogu da utiču na rast bakterija u mesu. U odnosu na početnu kontaminaciju, broj Salmonella spp. u mariniranim i soljenim filetima nije se značajno menjao $(\mathrm{p}<0,001)$ do 3., odnosno 6. dana skladištenja, ali se značajno povećao do 9. dana skladištenja. Mariniranje fileta grudi brojlera u različitim rastvorima kuhinjske soli, natrijum tripolifosfat $i /$ ili natrijum citrata imalo 
je značajan uticaj $(\mathrm{p}<0,05 ; \mathrm{p}<0,01)$ na promenu $\mathrm{pH}$ vrednosti mesa, sadržaj vlage $\mathrm{i}$ pepela i sadržaj soli u mariniranom mesu, ali nije utvrđen značajan uticaj ( $>>0,05)$ na promenu sadržaja proteina i masti u mesu brojlera. $\mathrm{Na}$ osnovu dobijenih rezultata može se zaključiti da mariniranje mesa grudi brojlera u rastvorima koji sadrže kuhinjsku so, natrijum tripolifosfat i/ili citrat, na neki način, može da produži lag fazu rasta Salmonella vrsta, gde je natrijum citrat efikasniji od natrijum tripolifosfata. 